\title{
Enhancement of an additive-manufactured austenitic stainless steel by post- manufacture heat-treatment
}

Chen, Nan; Ma, Guoqiang; Zhu, Wanquan; Godfrey, Andrew William; Shen, Zhijian; Wu, Guilin; Huang, Xiaoxu

Published in:

Materials Science and Engineering: A - Structural Materials: Properties, Microstructure and Processing

Link to article, DOI:

10.1016/j.msea.2019.04.111

Publication date:

2019

Document Version

Peer reviewed version

Link back to DTU Orbit

Citation (APA):

Chen, N., Ma, G., Zhu, W., Godfrey, A. W., Shen, Z., Wu, G., \& Huang, X. (2019). Enhancement of an additivemanufactured austenitic stainless steel by post-manufacture heat-treatment. Materials Science and Engineering: A - Structural Materials: Properties, Microstructure and Processing, 759, 65-69. https://doi.org/10.1016/j.msea.2019.04.111

\section{General rights}

Copyright and moral rights for the publications made accessible in the public portal are retained by the authors and/or other copyright owners and it is a condition of accessing publications that users recognise and abide by the legal requirements associated with these rights.

- Users may download and print one copy of any publication from the public portal for the purpose of private study or research.

- You may not further distribute the material or use it for any profit-making activity or commercial gain

- You may freely distribute the URL identifying the publication in the public portal 


\title{
Enhancement of an additive-manufactured austenitic stainless steel by post-manufacture heat-treatment
}

Nan Chen ${ }^{\mathrm{a}}$, Guoqiang Ma ${ }^{\mathrm{a}}$, Wanquan Zhu ${ }^{\mathrm{a}}$, Andrew Godfrey ${ }^{\mathrm{b}}$, Zhijian Shen ${ }^{\mathrm{c}}$, Guilin $\mathrm{Wu}^{\mathrm{a},{ }^{*}}$, Xiaoxu Huang ${ }^{\mathrm{a}, \mathrm{d}}$

${ }^{a}$ International Joint Laboratory for Light Alloys (MOE), College of Materials Science and Engineering, Chongqing University, Chongqing, 400044, China;

${ }^{b}$ Laboratory of Advanced Materials (MOE), School of Materials Science and Engineering, Tsinghua University, Beijing, 100084, China;

${ }^{\mathrm{c} D e p a r t m e n t}$ of Materials and Environmental Chemistry, Arrhenius Laboratory, Stockholm University, 10691 Stockholm, Sweden;

${ }^{\mathrm{d}}$ Department of Mechanical Engineering, Technical University of Denmark, DK-2800 Lyngby, Denmark

* Corresponding author: G.L. Wu, wugl@cqu.edu.cn

\begin{abstract}
:
The effect of post-manufacture heat-treatment on the mechanical strength of an additively-manufactured austenitic stainless steel has been investigated. Microstructural investigations revealed that the as-manufactured material exhibited a multi-scale structure, composed of grains, cells, dislocations and nano-sized particles. Annealing at $400^{\circ} \mathrm{C}$ resulted in a $10 \%$ increase in yield strength, associated with the additional precipitation of a population of nano-sized silicates. Annealing at higher temperatures resulted in a decrease in strength, attributed primarily to the thermal instability of the cell structure in the as-manufactured material. The results demonstrate that by careful control of annealing conditions the structure and mechanical properties of additively-manufactured austenitic stainless steel can be optimized by postmanufacture heat-treatment.
\end{abstract}


Keywords: Additive manufacturing; 316L stainless steel; heat-treatment; mechanical properties; Orowan strengthening

\section{Introduction}

Additive manufacturing (AM) is a rapidly developing technology, combining computer-aided design with material processing and forming to allow the creation of solid objects [1-10]. Among the various AM methods, selective laser melting (SLM) is of increasing interest for the manufacture of engineering materials. In this method a high-energy laser beam is used to melt locally a bed of metal powder according to a pre-determined design, resulting in the manufacture of a two-dimensional cross-section [8-10], with solid parts achieved by repeating this process layer-by-layer from bottom to top to form the final part $[8,11]$. This "bottom-up" AM method allows the production of complex structural parts that cannot be achieved by traditional processing methods.

316L stainless steel (316L SS) is an austenitic composition with high strength and good corrosion resistance, widely used in the aerospace, energy, and automotive industries, as well as in medical devices [3,8]. Due both to its relatively high machining costs, and to its high sensitivity to grain boundary corrosion after welding, there is increasing interest in the manufacture of $316 \mathrm{~L}$ SS parts by AM, through which nearnet-shape components can be produced.

In addition to optimization of the process parameters during AM, the mechanical properties and performance of additively-manufactured components can also be modified by post-manufacture heat-treatment. For example, the occurrence of phase transformations has been reported in additively-manufactured 316L SS after annealing at high temperature [4]. A key point, however, is that the high strength and good ductility of additively-manufactured 316L SS has been attributed in part to the presence of a dislocation network structure [12]. As annealing at elevated temperatures can result in a reduction in dislocation density via thermally-activated recovery processes, this may therefore result in a deterioration in mechanical properties. Accordingly, it is necessary to study carefully the link between the thermal stability of the dislocation 
network structure and changes in mechanical properties during annealing of additivelymanufactured 316L SS.

\section{Experimental}

The material used in this study is an additively-manufactured $316 \mathrm{~L} \mathrm{SS}$, produced by the SLM method. Detailed information regarding the material is given in [12]. Samples for investigation were cut by spark machining, mechanically polished, and then annealed for $1 \mathrm{~h}$ at various temperatures up to $800^{\circ} \mathrm{C}$, followed in each case by water cooling.

Micro-hardness was measured using a load of $1 \mathrm{~kg}$ and a dwell time of $10 \mathrm{~s}$. Ten measurements were performed on each sample. Dog-bone shaped tensile specimens with a gauge size of $8 \mathrm{~mm}$ in length, $2 \mathrm{~mm}$ in width and $1 \mathrm{~mm}$ in thickness, were cut with the tensile axis perpendicular to the build direction. The samples were tested at a constant strain rate of $4 \times 10^{-4} \mathrm{~s}^{-1}$.

Microstructural characterization was carried out using an Oxford AZtec electron backscattered diffraction (EBSD) detector attached to a JEOL 7800F scanning electron microscope (SEM), and a JEOL 2100 transmission electron microscope (TEM). Samples for EBSD were mechanically polished followed by electropolishing at $20 \mathrm{~V}$ for $10 \mathrm{~s}$ in an electrolyte of perchloric acid and acetic acid (1:4 ratio) at room temperature (RT). Analysis of the EBSD data was carried out using the Oxford Instruments Channel 5 software package. Specimens for TEM investigation were ground to approximately $50 \mu \mathrm{m}$ thickness, and then thinned by jet-polishing using a voltage of $50 \mathrm{~V}$ at $-20^{\circ} \mathrm{C}$ in an $5 \%$ perchloric acid/ethanol solution. The chemical composition was analyzed using energy-dispersive X-ray spectroscopy (EDS) in a FEI TECNAI G2 F20 TEM.

\section{Results and discussion}

Fig. 1(a) shows the micro-hardness of the additively manufactured 316L SS as a function of heat-treatment temperature. The micro-hardness of the as-manufactured material is $252 \mathrm{HV}$. With increasing annealing temperature, the micro-hardness first 
gradually increases to a maximum value of $291 \mathrm{HV}$ at $400^{\circ} \mathrm{C}$, and then continuously decreases to $228 \mathrm{HV}$ at $800^{\circ} \mathrm{C}$. Fig. 1(b) shows tensile curves of the as-manufactured sample and of samples annealed at $400^{\circ} \mathrm{C}$ and $800^{\circ} \mathrm{C}$ for $1 \mathrm{~h}$. The yield strength and uniform elongation in the as-manufactured condition are $586 \mathrm{MPa}$ and $35 \%$, respectively. After annealing at $400^{\circ} \mathrm{C}$ for $1 \mathrm{~h}$, the yield strength increases to $642 \mathrm{MPa}$, while the uniform elongation only slightly decreases to $32 \%$. After annealing at $800^{\circ} \mathrm{C}$ for $1 \mathrm{~h}$, the yield strength decreases to $482 \mathrm{MPa}$ and the uniform elongation is restored to $35 \%$.
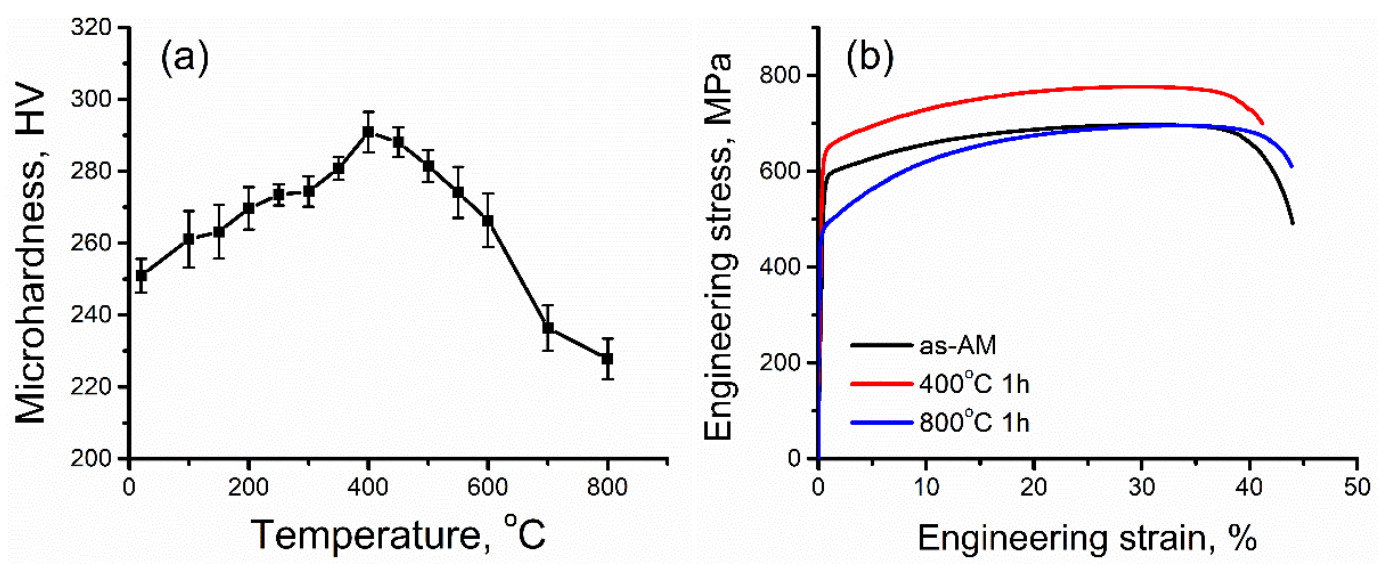

Fig. 1 (a) Micro-hardness of additively-manufactured 316L SS after annealing at various temperatures for $1 \mathrm{~h}$; (b) engineering stress-strain curves of the as-manufactured $316 \mathrm{~L} \mathrm{SS}$ sample and of samples annealed at $400^{\circ} \mathrm{C}$ and $800^{\circ} \mathrm{C}$ for $1 \mathrm{~h}$.

Fig. 2 shows example EBSD orientation maps of the as-manufactured sample and of samples annealed at $400^{\circ} \mathrm{C}$ and $800^{\circ} \mathrm{C}$ for $1 \mathrm{~h}$. The EBSD maps reveal a microstructure typical of additively-manufactured material, namely a checkerboard macrostructure in the section perpendicular to the build direction (as shown in Figs. 2(a-c)), and a columnar grain structure in sections containing the build direction (as seen in Figs. 2(d-f)) [12]. This microstructural appearance has been attributed to rapid melting and solidification away from equilibrium conditions during the AM process [4, 12]. Grain sizes were determined from the EBSD maps using an area reconstruction method with a $2^{\circ}$ grain boundary definition, and are given in Table 1 as equal circular 
diameter values. The average grain size in the as-manufactured sample is about $5.9 \mu \mathrm{m}$, with only a small variation observed after annealing at either $400^{\circ} \mathrm{C}$ or $800^{\circ} \mathrm{C}$.
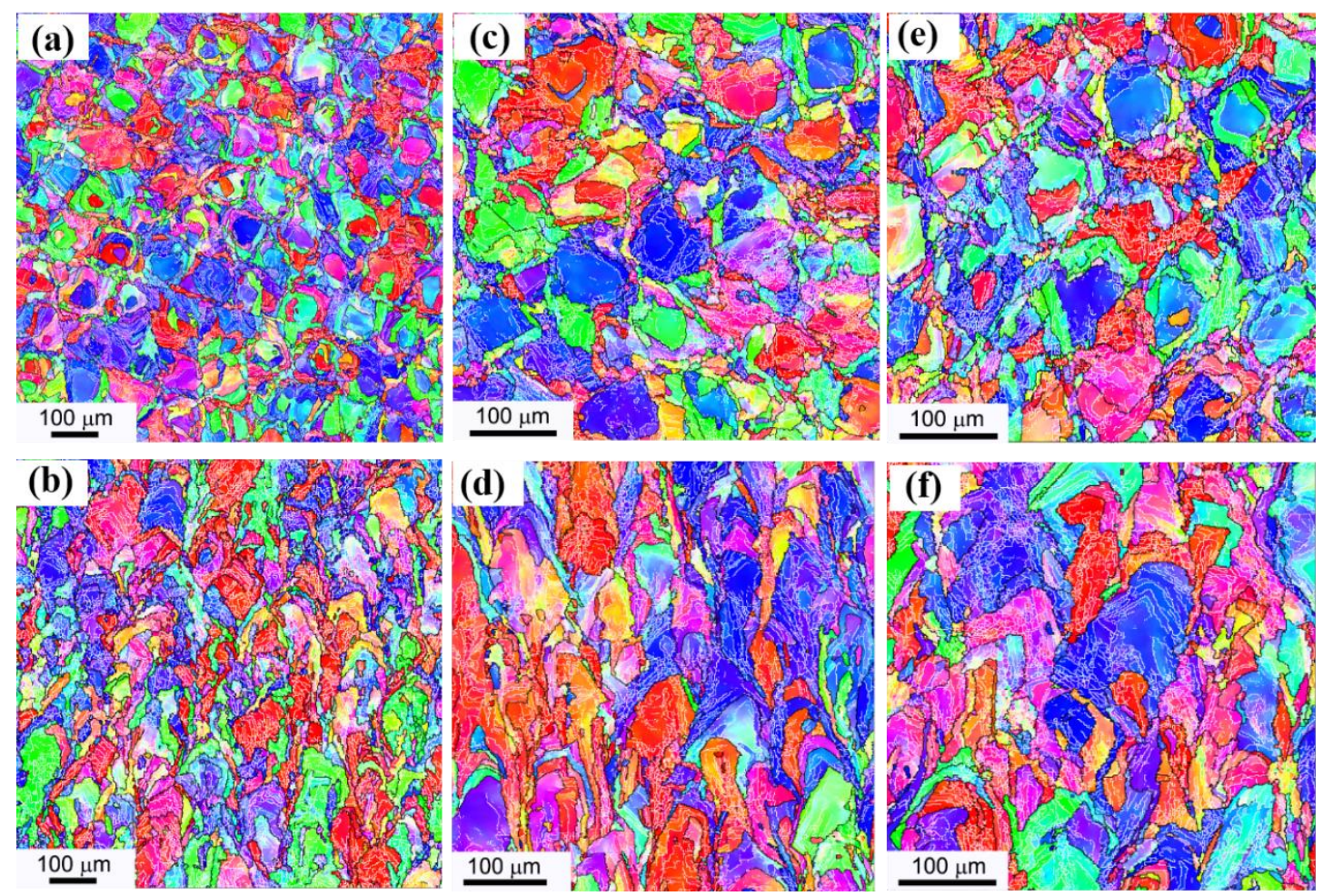

Fig. 2 EBSD orientation maps of the as-manufactured sample (a, b), and of samples annealed at $400^{\circ} \mathrm{C}(\mathrm{c}, \mathrm{d})$ and $800^{\circ} \mathrm{C}(\mathrm{e}, \mathrm{f})$ for $1 \mathrm{~h}$. The microstructure in the section taken perpendicular to the build direction is shown in $(\mathrm{a}, \mathrm{c}, \mathrm{e})$, while $(\mathrm{b}, \mathrm{d}, \mathrm{f})$ show a section containing the build direction. White lines represent misorientations $\geq 2^{\circ}$ and $<15^{\circ}$, with black lines showing misorientations $\geq 15^{\circ}$.

Fig. 3 shows TEM images of the as-manufactured sample and of samples annealed at $400^{\circ} \mathrm{C}$ and $800^{\circ} \mathrm{C}$ for $1 \mathrm{~h}$. As shown in Fig. 3(a) and 3(b), a characteristic cell structure is seen in the as-manufactured sample, similar to that seen previously in additivelymanufactured 316L SS $[6,12]$. In some regions cellular sub-grains are observed (Fig. 3(a)), whereas other regions are composed of columnar sub-grains (Fig. 3(b)) [7]. The average cell diameter, as determined from TEM images showing cells with an equiaxed morphology, is about $0.48 \mu \mathrm{m}$ (see Table 1), with a columnar length of more than 10 $\mu \mathrm{m}$. Many dislocations are also observed within the cells. 
Table 1 Microstructural parameters and calculated Orowan strengthening contributions

\begin{tabular}{lccc}
\hline Sample & as-manufactured & $400^{\circ} \mathrm{C} / 1 \mathrm{~h}$ & $800^{\circ} \mathrm{C} / 1 \mathrm{~h}$ \\
\hline Average grain size, $\mu \mathrm{m}$ & 5.9 & 5.6 & 5.4 \\
Average cell diameter, $\mu \mathrm{m}$ & 0.48 & 0.50 & 0.46 \\
Volume fraction of particles $(f), \%$ & 0.42 & 1.38 & 0.61 \\
Average particle size $(d), \mathrm{nm}$ & 64 & 21 & 14 \\
Average particle spacing $(\lambda), \mu \mathrm{m}$ & 10.1 & 0.97 & 1.49 \\
Orowan strengthening $(\Delta \sigma), \mathrm{MPa}$ & 6 & 61 & 40 \\
\hline
\end{tabular}

After annealing at $400^{\circ} \mathrm{C}$ for $1 \mathrm{~h}$, both the cell structure and the high density of cellinterior dislocations are preserved (Figs. 3(c) and 2(d)), with almost no detectable change in the average cell diameter (see Table 1). The characteristic cell structure of the as-manufactured sample is therefore thermally stable at temperatures up to $400^{\circ} \mathrm{C}$. However, after annealing at $800^{\circ} \mathrm{C}$ for $1 \mathrm{~h}$ (Figs. 2(e) and 2(f)), a significant change in the dislocation structure is observed, with the microstructural appearance changing to be more typical of that seen in $316 \mathrm{~L}$ SS after plastic deformation at elevated temperatures [13]. Interestingly, however, the length scale of the dislocation cell structure remains almost unchanged.

For each sample five areas were characterized using the TEM observations to determine both the volume fraction and average size of silicates. The results are listed in Table 1. It is seen that in the as-manufactured sample the volume fraction of silicates is only $0.42 \%$, and that these silicates have a relatively large average size. After annealing at $400^{\circ} \mathrm{C}$ for $1 \mathrm{~h}$, the volume fraction of silicates increases to $1.36 \%$, indicating that precipitation of silicates takes place during annealing at $400^{\circ} \mathrm{C}$. The newly precipitated silicates are small in size, resulting in a decrease in the average silicate particle size. After annealing at $800^{\circ} \mathrm{C}$, some dissolution of the silicates takes place, resulting in a decrease in the volume fraction to $0.61 \%$, accompanied by a small decrease in the average particle size. 

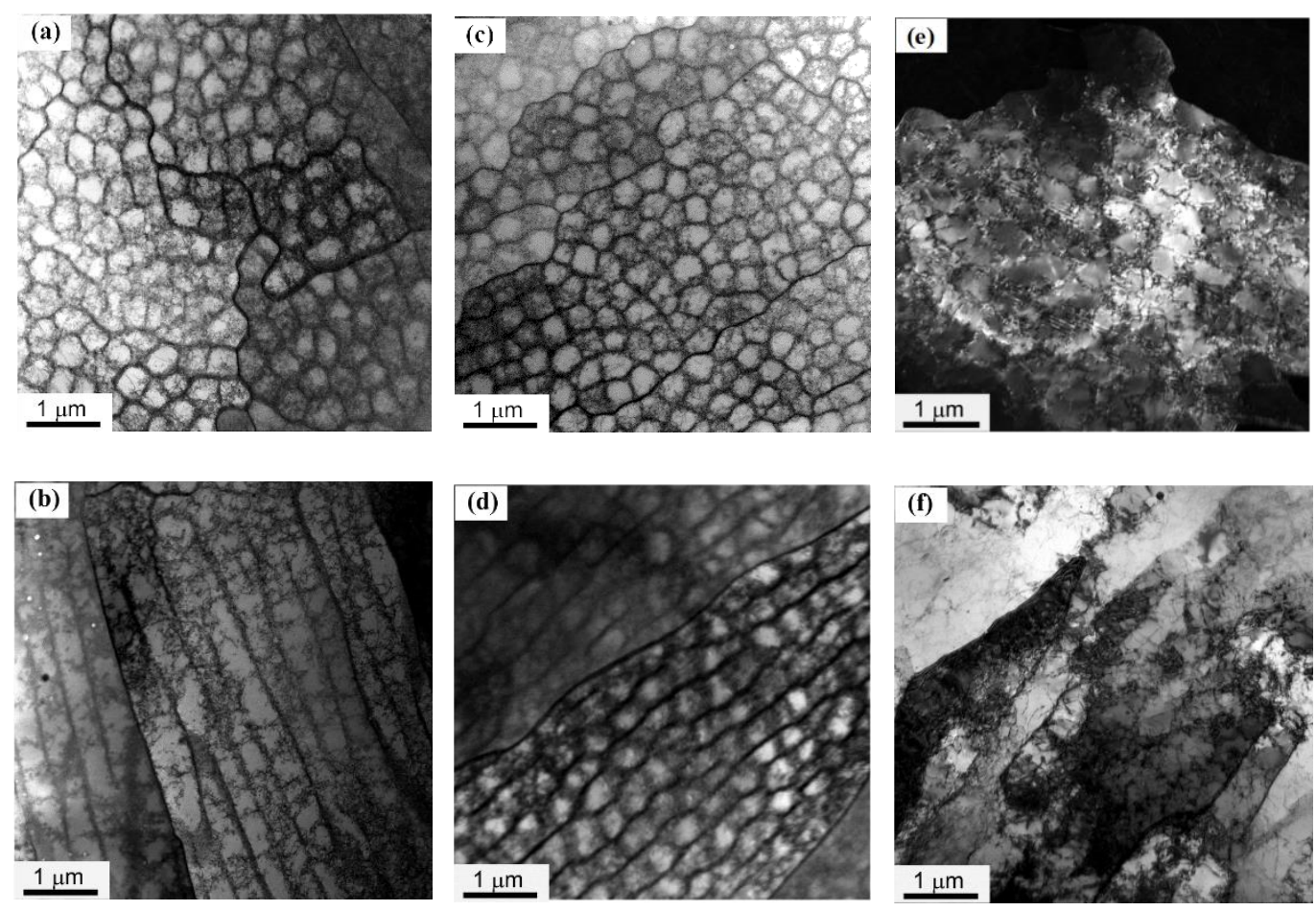

Fig. 3 TEM images of the as-manufactured sample (a, b), and of samples annealed at $400^{\circ} \mathrm{C}(\mathrm{c}, \mathrm{d})$ and $800^{\circ} \mathrm{C}(\mathrm{e}, \mathrm{f})$ for $1 \mathrm{~h}$. Examples of cell structures are shown in micrographs (a), (c) and (e), while examples of columnar structures are shown in (b), (d) and (f).

The contribution to the tensile yield strength of the silicates $(\Delta \sigma)$ can be estimated according to the Orowan mechanism, as described by:

$$
\Delta \sigma=M \cdot \Delta \tau=M \cdot \frac{G \cdot b}{\lambda}
$$

where $M$ is the Taylor factor, $\tau$ the shear stress, $G$ the shear modulus, $b$ the Burgers vector, and $\lambda$ the average spacing of the silicate particles. Here, $\lambda$ is determined using the equation:

$$
\lambda=\frac{4(1-f) r}{3 f}
$$

where $f$ is the volume fraction, and $r$ is the average radius of the silicate particles. Based on these equations, and using the values given in Table 1, the strength contributions due to the silicate particles have been estimated, taking values of $M=3.06, G=77.2 \mathrm{GPa}$ and $b=0.256 \mathrm{~nm}$. The results are given in Table 1 . It is seen that the silicate particles 
contribute very little to the yield strength of the as-manufactured sample, due both to their small volume fraction and the large average particle size. However, in the sample annealed at $400^{\circ} \mathrm{C}$ for $1 \mathrm{~h}$ he newly precipitated silicates contribute about $55 \mathrm{MPa}$ to the yield strength - almost completely accounting for the increase in strength of the asmanufactured sample after annealing at this temperature $(56 \mathrm{MPa})$.
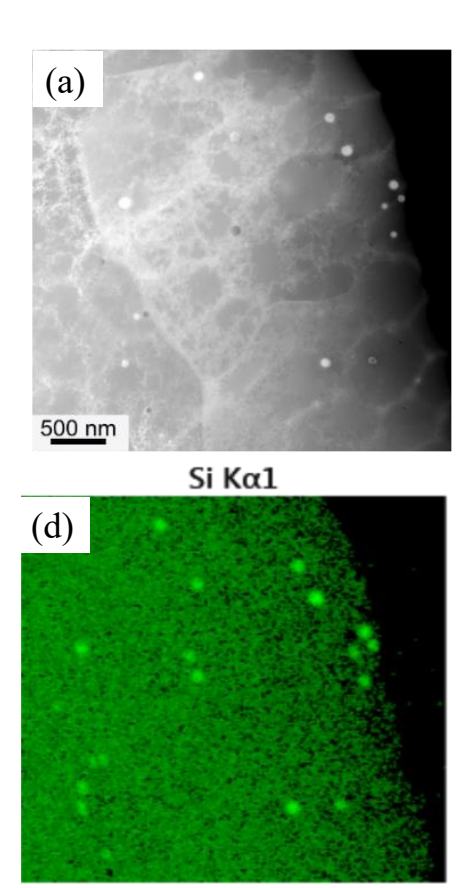

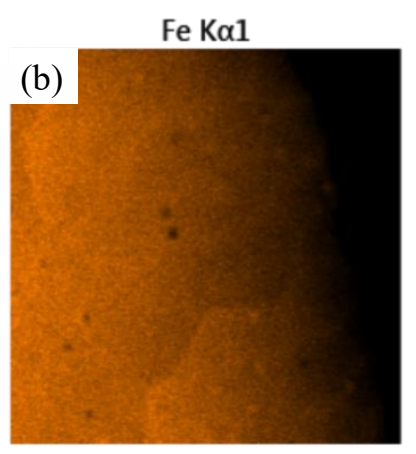

$\mathrm{O} K \alpha 1$

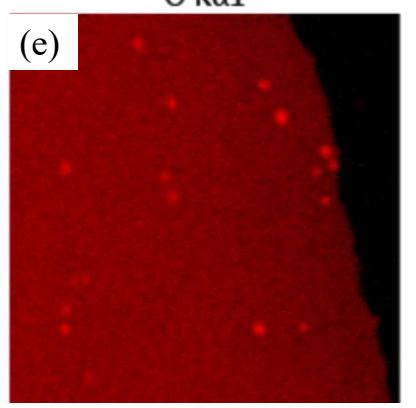

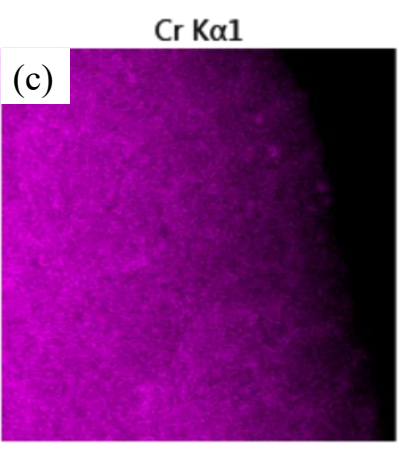

$\mathrm{Mn} K \alpha 1$

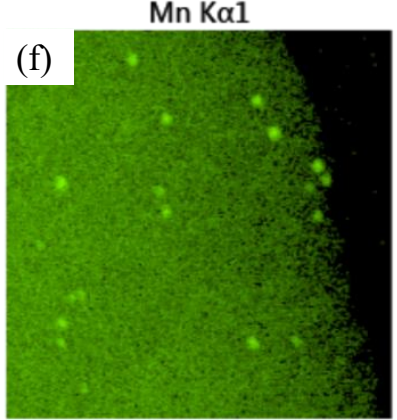

Fig. 4 Example EDS mapping showing the presence of silicates in the sample annealed at $400^{\circ} \mathrm{C}$ for $1 \mathrm{~h}$. (a) TEM image; (b), (c), (d), (e) and (f) are element distribution maps of $\mathrm{Fe}, \mathrm{Cr}, \mathrm{Si}, \mathrm{O}$ and $\mathrm{Mn}$, respectively.

Interestingly, based on the microstructural parameters the silicate particles are predicted to give a strength contribution of $34 \mathrm{MPa}$ after annealing at $800^{\circ} \mathrm{C}$ for $1 \mathrm{~h}$. Annealing at $800^{\circ} \mathrm{C}$ for $1 \mathrm{~h}$ in fact results, however, in a decrease of the yield strength of $104 \mathrm{MPa}$ compared to the as-manufactured sample. Moreover, the length scale of the dislocation cell structure in this condition is comparable to that of both the asmanufactured sample and of the sample annealed at $400^{\circ} \mathrm{C}$ for $1 \mathrm{~h}$ (as seen in Table 1). The appearance of the cell structure is, however, very different in the sample annealed 
at $800^{\circ} \mathrm{C}$, indicating that at this temperature significant modifications to the dislocation arrangements forming the cell structure have taken place.

These observations highlight the importance of preserving the dislocation cell structure of the as-manufactured material during any subsequent heat-treatment, and shows additionally that a window of annealing temperatures exists where the cell structure can be preserved while also taking advantage of other strengthening mechanisms. The exact origin of the strength contribution from the dislocation cell structure is not yet fully understood, and further studies to examine the specific changes in the dislocation arrangements in the cell structure that take place during annealing are necessary.

A consideration that should be taken into account in this regard is that annealing of 316L SS may introduce sensitization of the grain boundaries. A preliminary study has shown, for example, that rapid attack on the boundaries of melting pools in additively manufactured $316 \mathrm{~L}$ SS may occur after annealing at $650^{\circ} \mathrm{C}$ for $1 \mathrm{~h}$ [15]. Therefore, it is also important to study the consequence of annealing on the corrosion behavior of additively manufactured 316L SS, even for low-carbon compositions that are traditionally considered as resistant to sensitization. Preliminary oxalic acid tests according the ASTM A262 Practice A [16] on the 316L SS material of this study show no sensitization of grain boundaries of the present as-manufactured and of the $800^{\circ} \mathrm{C}$ annealed samples [see supplementary material].

The results of the present study show that additive manufacturing of $316 \mathrm{~L} \mathrm{SS}$ results in a multi-scale structure. On the melt pool scale, a checkerboard pattern is formed, consisting of grains with size of up to tens of micrometers, separated in many cases by high angle boundaries. Inside these grains, a cell structure is developed, where the average cell size is a few hundred nanometers. Within these cells, a high density of dislocations and a population of nano-sized silicate particles are found. This multi-scale structure results in a yield strength of the as-additively manufactured 316L SS of 586 $\mathrm{MPa}$, very close to that reported elsewhere $[6,12]$. During annealing at temperatures up to $400^{\circ} \mathrm{C}$ fine silicate particles are precipitated, while the cell structure and dislocations are stable. This results in a gradual increase in micro-hardness and yield 
strength. However, annealing at higher temperatures leads to a continuous decrease in micro-hardness and yield strength, despite the continued presence of a population of silicate particles, suggesting that at temperatures higher than $400^{\circ} \mathrm{C}$ a transformation of cell/dislocation structure take place, resulting in a reduced strength contribution. This conclusion is supported by the observation of a change in the appearance of the cell structure in the sample annealed at $800^{\circ} \mathrm{C}$.

\section{Conclusions}

The microstructural stability and mechanical properties of additively manufactured 316L SS during post-manufacture heat treatment have been studied by annealing at temperatures up to $800^{\circ} \mathrm{C}$ for $1 \mathrm{~h}$. Annealing at temperatures up to $400^{\circ} \mathrm{C}$ leads to an $10 \%$ increase in yield strength compared to the as-manufactured state, from $586 \mathrm{MPa}$ to $642 \mathrm{MPa}$, with only a small loss in uniform elongation. This is attributed to the thermal stability of the cell/dislocation structure, in combination with precipitation of nano-sized silicate particles. The preservation of the cell/dislocation structure allows the high strength and good ductility of the as-manufactured material to be maintained, while the silicates contribute via an Orowan mechanism to the majority of the observed strength increase of $56 \mathrm{MPa}$ in the sample annealed at $400{ }^{\circ} \mathrm{C}$ for $1 \mathrm{~h}$. Annealing at temperatures higher than $400^{\circ} \mathrm{C}$ results, however, in a continuous decrease in the strength of the material, as the cell structure is no longer stable, and some dissolution of the silicates takes place.

The present study shows that by careful control of the annealing conditions the mechanical properties of additively-manufactured $316 \mathrm{~L} \mathrm{SS}$ can be further increased by post-manufacture heat treatment, providing a route for enhancement in mechanical properties of additively-manufactured 316L SS parts in addition to optimization of the AM processing parameters. The results also highlight the importance of understanding the strength contribution and thermal stability of the cell structure formed during additive manufacturing, and how these relate to the nature of the dislocation 
arrangements in the as-manufactured and annealed conditions. Although the results presented here are for $316 \mathrm{~L} \mathrm{SS}$, the findings of the present study can be also applied to other heat-treatable metallic materials produced using additive manufacturing, thus pointing to a new avenue for tailoring the mechanical properties of additivemanufactured parts by controlled heat-treatments.

\section{Acknowledgements}

The State Key Research \& Development Program of MOST of China (2016YFB0700403, 2016YFB0700401), National Natural Science Foundation of China (Nos.51471039 and 51421001) and the Fundamental Research Funds for the Central Universities (No. 2018CDJDCL0019) are greatly acknowledged.

\section{References}

[1] M.S.F. de Lima, S. Sankaré, Microstructure and mechanical behavior of laser additive manufactured AISI 316 stainless steel stringers, Mater. Des. 55 (2014) 526532.

[2] Z. Sun, X. Tan, S.B. Tor, W.Y. Yeong, Selective laser melting of stainless steel 316L with low porosity and high build rates, Mater. Des. 104 (2016) 197-204.

[3] K. Saeidi, X. Gao, Y. Zhong, Z.J. Shen, Hardened austenite steel with columnar subgrain structure formed by laser melting, Mater. Sci. Eng. A 625 (2015) 221-229.

[4] K. Saeidi, X. Gao, F. Lofaj, L. Kvetková, Z.J. Shen, Transformation of austenite to duplex austenite-ferrite assembly in annealed stainless steel $316 \mathrm{~L}$ consolidated by laser melting, J. Alloy. Compd. 633 (2015) 463-469.

[5] Y. Zhong, L. Liu, S. Wikman, D. Cui, Z. Shen, Intragranular cellular segregation network structure strengthening 316L stainless steel prepared by selective laser melting, J. Nucl. Mater. 470 (2016) 170-178.

[6] Y.M. Wang, T. Voisin, J.T. McKeown, J. Ye, N.P. Calta, Z. Li, Z. Zeng, Y. Zhang, W. Chen, T.T. Roehling, R.T. Ott, M.K. Santala, P.J. Depond, M.J. Matthews, A.V. Hamza, T. Zhu, Additively manufactured hierarchical stainless steels with high strength and ductility, Nat. Mater. 17 (2018) 63-71.

[7] M.S. Pham, B. Dovgyy, P.A. Hooper, Twinning induced plasticity in austenitic stainless steel 316L made by additive manufacturing, Mater. Sci. Eng.: A 704 (2017) 102-111.

[8] I. Tolosa, F. Garciandía, F. Zubiri, F. Zapirain, A. Esnaola, Study of mechanical properties of AISI 316 stainless steel processed by "selective laser melting", following different manufacturing strategies, Int. J. Adv. Manuf. Technol. 51 (2010) 639-647. 
[9] R. Casati, J. Lemke, M. Vedani, Microstructure and Fracture Behavior of 316L Austenitic Stainless Steel Produced by Selective Laser Melting, J. Mater. Sci. Technol. 32(8) (2016) 738-744.

[10] G.T. Gray, V. Livescu, P.A. Rigg, C.P. Trujillo, C.M. Cady, S.R. Chen, J.S. Carpenter, T.J. Lienert, S.J. Fensin, Structure/property (constitutive and spallation response) of additively manufactured 316L stainless steel, Acta Mater. 138 (2017) 140-149.

[11] D. Wang, C. Song, Y. Yang, Y. Bai, Investigation of crystal growth mechanism during selective laser melting and mechanical property characterization of $316 \mathrm{~L}$ stainless steel parts, Mater. Des. 100 (2016) 291-299.

[12] L. Liu, Q. Ding, Y. Zhong, J. Zou, J. Wu, Y.-L. Chiu, J. Li, Z. Zhang, Q. Yu, Z. Shen, Dislocation network in additive manufactured steel breaks strengthductility trade-off, Mater. Today 21 (2018) 354-361.

[13] K. Saeidi, L. Kvetková, F. Lofaj, Z. Shen, Austenitic stainless steel strengthened by the in situ formation of oxide nanoinclusions, RSC Adv. 5.(2015) 20747-20750.

[14] F. Yan, W. Xiong, E. Faierson, G.B. Olson, Characterization of nano-scale oxides in austenitic stainless steel processed by powder bed fusion, Scr. Mater. 155 (2018) 104-108.

[15] D.A. Macatangay, S. Thomas, N. Birbilis, R.G. Kelly, Unexpected interface corrosion and sensitization susceptibility in additively manufactured austenitic stainless steel, Corr. Comm. 74 (2018) 153-157.

[16] https://www.astm.org/Standards/A262.htm. 